\title{
Late Leaf Spot Severity and Yield of New Peanut Breeding Lines and Cultivars Grown Without Fungicides
}

Brian S. Jordan, Albert K. Culbreath, ${ }^{\dagger}$ Timothy B. Brenneman, and Robert C. Kemerait Jr., Department of Plant Pathology, The University of Georgia, Tifton, 31793-5766; and William D. Branch, Department of Crop and Soil Sciences, The University of Georgia, Tifton, $31793-5766$

\begin{abstract}
Peanut (Arachis hypogaea) cultivars with resistance or tolerance to Cercospora arachidicola and/or Cercosporidium personatum, the causes of early and late leaf spot, respectively, are needed for organic production in the southeastern U.S. To determine the potential of new breeding lines for use in such production systems, field experiments were conducted in Tifton, GA, in 2014 and 2015 in which nine breeding lines and two cultivars, Georgia-06G and Georgia-12Y, were grown without foliar fungicide applications. In one set of trials, cultivar Georgia-12Y and most of the breeding lines evaluated had early season vigor ratings, early-season canopy width measurements, final plant populations, and pod yield that were greater than those of standard cultivar Georgia-06G. In those trials, final late leaf spot Florida scale ratings were lower and canopy reflectance measured as the normalized difference vegetation index (NDVI), was higher all the

breeding lines than those of Georgia-06G. In another set of trials, two of those same breeding lines had final late leaf spot ratings similar to those of Georgia$12 \mathrm{Y}$ in 2014, whereas in 2015, six of those breeding lines had final leaf spot ratings that were lower than those of Georgia-12Y. Yields were similar for Georgia-12Y and all the breeding lines in the Gibbs Farm trials. Across years and breeding lines at the Lang Farm, the relationship between visual estimates of defoliation and NDVI was described by a two sector piecewise regression with NDVI decreasing more rapidly with increasing defoliation above approximately $89 \%$. The utility of NDVI for spot comparisons among breeding lines appears to be limited to situations where there are differences in defoliation. Georgia-12Y and multiple breeding lines evaluated show potential for use in situations such as organic production where acceptable fungicides available for seed treatment and leaf spot control are limited.
\end{abstract}

Early leaf spot and late leaf spot, caused by Cercospora arachidicola S. Hori and Cercosporidium personatum (Berk. \& M. A. Curtis) Deighton, respectively, are among the most destructive diseases of peanut (Arachis hypogaea L.) worldwide. In the southeastern U.S., they cause direct losses to peanuts through yield reduction and increased management associated with multiple fungicide applications. Recent estimates for combined direct losses in yield and cost of control attributable to these diseases have been as high as $\$ 39.7$ million for Georgia alone (Langston 2009). If not managed, either disease or the combination of the two can cause complete defoliation. High levels of defoliation often result in loss of integrity of the gynophores by which pods are attached to the plant and loss of mature pods when peanut plants are inverted (Knauft et al. 1988; Teare et al. 1984).

Control of leaf spot diseases in the U.S. is very dependent on fungicides (Branch and Culbreath 2008). Although effective fungicides are available for use in conventional production, they represent potential risks to the environment, the applicator, and consumers (Branch and Culbreath 2008). They are also expensive, with estimated cost of $\$ 216 /$ ha per year, representing approximately $13.7 \%$ of the variable costs for irrigated peanut production in Georgia (Rabinowitz and Smith 2017). Synthetic pesticides cannot be used in organic peanut production, and fungicides that can be used are limited (Cantonwine et al. 2008). Cultivars that have high yield potential and resistance or tolerance to leaf spot diseases would be of benefit to both conventional and organic production systems, but will be necessary for large-scale production in organic systems.

Stand establishment is important for management of tomato spotted wilt, caused by Tomato spotted wilt virus in conventional as well as organic production (Culbreath and Srinivasan 2011; Kemerait et al. 2016). Cultivars that germinate and emerge quickly with either resistance to prominent damping off pathogens or that are vigorous enough to escape

${ }^{\dagger}$ Corresponding author: A. K. Culbreath, E-mail: spotwilt@uga.edu

Accepted for publication 21 May 2017.

(c) 2017 The American Phytopathological Society damage by the pathogens would be desirable for both conventional and organic production. Such characteristics would be especially beneficial in organic production systems since few organically acceptable seed treatments are available that provide consistent stand establishment (Cantonwine et al. 2011). In organic production, stand establishment and rapid coverage of the ground by young peanut plants would also help with weed management. Observations in earlier experiments and in production fields indicated that the runner-type peanut cultivar, Georgia12Y (Branch 2013), may have potential to improve stand establishment efficiency and reduce time until row middles are covered compared with the predominant cultivar Georgia-06G (Branch 2007). Several advanced breeding lines have shown similar potential in preliminary trials. Additional characterization of these variables is needed to determine which breeding lines have best potential for use in systems where effective fungicides for foliar disease management or seed treatments are limited.

Visual estimates of percent defoliation or use of the Florida 1-10 severity scale (Chiteka et al. 1988) are effective means of assessing early or late leaf spot in peanut. However, both are subjective, and estimates can vary among evaluators. Measurements of canopy reflectance in the $800 \mathrm{~nm}$ wavelength range have been used to assess leaf spot severity (Aquino et al. 1992; Nutter and Littrell 1996). More recently, Navia Gine (2012) found that a normalized difference vegetation index (NDVI) correlated more closely with percent defoliation by leaf spot in Georgia-06G than reflectance in the near-infrared range. However, the utility of reflectance measurements for evaluating multiple genotypes for response to leaf spot diseases has not been evaluated.

The primary objective of this study was to determine the effect of nine advanced breeding lines and Georgia-12Y on leaf spot epidemics and on yield when grown without application of fungicides for control of leaf spot diseases. Objectives also included determining the effect of new cultivars and breeding lines on stand establishment and early season ground coverage. A secondary objective of this study was to determine how NDVI measurements relate to visual leaf spot assessments and whether they might be useful for evaluating genotypes for leaf spot resistance in the field.

\section{Materials and Methods}

Experimental design, layout, and source of plant materials. Field experiments were conducted in 2014 and 2015 at The University 
of Georgia, Coastal Plain Experimental Station (UGA-CPES). In each year, one trial was conducted at the Gibbs Farm and one trial at the Lang Farm. The soil type in all fields was a Tifton sandy loam (fine sandy, siliceous thermic Plinthic Paleudult). All the fields from both years had a history of moderate to heavy infestations of $C$. arachidicola or $C$. personatum in previous years when peanut was grown. Cotton (Gossyspium hirsutum) was grown in the previous respective season in each of the fields used in this study. Peanuts were planted 14 April 2014 and 10 April 2015 at the Gibbs Farm, and 30 May 2014 and 20 May 2015 at the Lang Farm. Seeding density was $14.8 \mathrm{seed} / \mathrm{m}$ of row in all trials.

A randomized complete block design was used in all trials. Five and three replications were used in 2014 and 2015, respectively, at the Gibbs Farm. Five and four replications were used in 2014 and 2015, respectively, at the Lang Farm. Plots were $6 \mathrm{~m}$ long by $1.8 \mathrm{~m}$ wide with two rows for each plot. All trials included nine advanced breeding lines that had been selected for field resistance to TSWV and C. personatum and yield potential when grown without foliar fungicides, and the cultivar Georgia-12Y (Table 1). All of the advanced breeding lines were developed from the cross of Georgia-05E (Branch 2006) $\times$ Georgia Browne (Branch 1994). Trials at the Lang Farm also included Georgia-06G, the predominant cultivar grown in the southeastern U.S. Georgia-12Y is a high-yielding cultivar with the highest level of field resistance to TSWV available (Culbreath et al. 2016). From preliminary trials, Georgia-12Y has shown indications of maintaining yield even with high levels of defoliation from leaf spot. Georgia-06G has a moderate-high level of field resistance to TSWV (Branch 2007; Culbreath et al. 2016), but is susceptible to $C$. arachidicola and C. personatum.

Plot establishment and environmental conditions. Soil temperature and rainfall records were obtained from the University of Georgia Automated Environmental Monitoring Network (http://www. georgiaweather.net/) for the station nearest the fields used. Rainfall and irrigation were measured at the Lang Farm with an on-site rain gauge. The average soil temperature indicated at the monitoring station at $10.2 \mathrm{~cm}$ depth for three days preceding planting date was $19.9^{\circ} \mathrm{C}$ in 2014 and $23.9^{\circ} \mathrm{C}$ in 2015 at the Gibbs Farm, and $27.9^{\circ} \mathrm{C}$ in 2014 and $22.8^{\circ} \mathrm{C}$ in 2015 at the Lang Farm. All plots were irrigated as needed. Rainfall amounts during the duration of the experiments at the Gibbs Farm were $15.3 \mathrm{~cm}$ in April, $21.4 \mathrm{~cm}$ in May, $7.3 \mathrm{~cm}$ in June, $7.6 \mathrm{~cm}$ in July, $3.8 \mathrm{~cm}$ in August, and $3.9 \mathrm{~cm}$ in September 2014 and $14.3 \mathrm{~cm}$ in April, $5.8 \mathrm{~cm}$ in May, $8.7 \mathrm{~cm}$ in June, $32.5 \mathrm{~cm}$ in July, $20.6 \mathrm{~cm}$ in August, and $0.05 \mathrm{~cm}$ in September 2015. Combined rainfall and irrigation amounts during the duration of the experiments at the Lang Farm were $2.4 \mathrm{~cm}$ in May, $10.1 \mathrm{~cm}$ in June, $12.5 \mathrm{~cm}$ in July, $15.2 \mathrm{~cm}$ in August, $16.4 \mathrm{~cm}$ in September, and $6.0 \mathrm{~cm}$ in October in 2014, and $2.3 \mathrm{~cm}$ in May, $13.0 \mathrm{~cm}$ in June, $32.3 \mathrm{~cm}$ in July, $18.4 \mathrm{~cm}$ in August, $5.5 \mathrm{~cm}$ in September, and $5.1 \mathrm{~cm}$ in October in 2015.

Seed treatments and assessment of vigor and plant population. At the Lang Farm, cultivars Georgia-06G and Georgia-12Y were planted with and without seed treatment. In both years, seed treatment consisted of azoxystrobin $0.128 \mathrm{~g} / \mathrm{kg}$ of seed, fludioxanil $0.008 \mathrm{~g} / \mathrm{kg}$ of seed, and mefenoxam $0.0016 \mathrm{~g} / \mathrm{kg}$ of seed applied as Dynasty PD (2.5 g/kg of seed) (Syngenta Crop Protection, Greensboro, NC). No seed treatment was used on any of the other breeding lines, and no seed treatment was used in the trials at the Gibbs Farm. At the Lang Farm in 2014, plant vigor was assessed 32 days after planting (DAP) using an ordinal $0-5$ scale where $0=$ no plants emerged; 1 = very sparse stand with 0 to $25 \%$ of the row covered; $2=$ sparse-moderate stand with 25 to $50 \%$ of the row covered; $3=$ moderate stand with 50 to $75 \%$ of the row covered; $4=$ few interruptions in row coverage with $>75 \%$ of the row covered and plants growing well; and $5=$ no interruptions in the row and plants uniformly growing well.

Canopy width was measured at six arbitrarily chosen points in each plot 32 DAP in 2014 and 56 DAP in 2015 at the Lang Farm and 56 DAP in 2015 at the Gibbs Farm. Canopy width measurements did not include areas in which there were no plants. Since canopy

Table 1. Median, mean rank $\left(\bar{R}_{i}.\right)$, and estimated relative treatment effects $\left(\hat{p}_{i}\right)$ with $95 \%$ confidence intervals $(\mathrm{CI})$ for plant vigor ratings, and mean early-season canopy width and final plant population in new peanut breeding lines and cultivar standards, The University of Georgia Lang Farm and Gibbs Farm, 2014-15

\begin{tabular}{|c|c|c|c|c|c|c|c|c|c|c|}
\hline \multirow[b]{3}{*}{ Genotype } & \multirow[b]{3}{*}{ Seed treatment } & \multicolumn{4}{|c|}{ Plant vigor rating ${ }^{a}$} & \multicolumn{3}{|c|}{ Canopy width ${ }^{\mathbf{b}}(\mathrm{cm})$} & \multicolumn{2}{|c|}{$\begin{array}{c}\begin{array}{c}\text { Final } \\
\text { population } \\
(\text { plants/m) }\end{array} \\
\text { (1) }\end{array}$} \\
\hline & & \multicolumn{4}{|c|}{ Lang 2014} & \multirow{2}{*}{$\frac{\text { Lang }}{2014}$} & \multirow{2}{*}{$\frac{\text { Lang }}{2015}$} & \multirow{2}{*}{$\frac{\text { Gibbs }}{2015}$} & \multirow{2}{*}{$\frac{\text { Lang }}{2015}$} & \multirow{2}{*}{$\frac{\text { Gibbs }}{2015}$} \\
\hline & & Median rating & $\overline{\boldsymbol{R}}_{\boldsymbol{i}}$. & $\hat{p}_{i}^{\mathrm{d}}$ & $95 \% \mathrm{CI}$ for $\hat{p}_{i}$ & & & & & \\
\hline GA072523 & None & 3.5 & 32 & 0.48 & $0.27,0.69$ & 25.6 & 83.5 & 61.1 & 11.0 & 10.8 \\
\hline GA072523-1 & None & 4.0 & 45 & 0.68 & $0.56,0.80$ & 26.5 & 86.5 & 55.5 & 10.8 & 10.3 \\
\hline GA072523-3 & None & 3.5 & 30 & 0.45 & $0.21,0.69$ & 25.4 & 86.7 & 62.8 & 10.9 & 10.2 \\
\hline GA072523-4 & None & 4.0 & 38 & 0.58 & $0.39,0.77$ & 27.3 & 87.9 & 60.1 & 10.9 & 10.6 \\
\hline GA072523-7 & None & 3.0 & 23 & 0.34 & $0.15,0.52$ & 23.1 & 82.1 & 53.9 & 11.8 & 10.2 \\
\hline GA072523-8 & None & 4.0 & 45 & 0.68 & $0.57,0.80$ & 25.8 & 89.3 & 62.1 & 10.7 & 10.6 \\
\hline GA072523-9 & None & 4.0 & 41 & 0.63 & $0.49,0.76$ & 27.9 & 86.0 & 61.7 & 11.5 & 10.3 \\
\hline GA072523-10 & None & 3.5 & 35 & 0.53 & $0.26,0.79$ & 25.7 & 86.7 & 59.4 & 11.7 & 10.8 \\
\hline GA072523-11 & None & 3.5 & 31 & 0.47 & $0.23,0.73$ & 25.1 & 82.3 & 63.7 & 10.9 & 11.4 \\
\hline Georgia-12Y & None & 4.0 & 48 & 0.72 & $0.48,0.96$ & 27.5 & 84.7 & 60.8 & 10.9 & 9.5 \\
\hline Georgia-12Y & Treated $^{\mathrm{e}}$ & 4.0 & 44 & 0.67 & $0.49,0.85$ & 27.9 & 84.3 & - & 10.9 & - \\
\hline Georgia-06G & None & 2.0 & 3 & 0.04 & $0.04,0.08$ & 21.3 & 75.1 & - & 9.3 & - \\
\hline Georgia-06G & Treated $^{\mathrm{e}}$ & 3.0 & 14 & 0.21 & $0.14,0.27$ & 23.7 & 72.9 & - & 9.0 & - \\
\hline $\operatorname{LSD}(P=0.05)$ & & & & & & 2.4 & 4.3 & $n s^{f}$ & 1.5 & $n s^{f}$ \\
\hline Mean square error & & & & & & 3.5 & 9.2 & 42.2 & 1.1 & 0.5 \\
\hline
\end{tabular}

a Plant vigor was assessed using an ordinal $0-5$ scale where $0=$ no plants emerged; $1=$ very sparse stand with 0 to $25 \%$ of the row covered; $2=$ sparse stand with 25 to $50 \%$ of the row covered; $3=$ moderate stand with 50 to $75 \%$ of the row covered; $4=$ few interruptions in row coverage with $>75 \%$ of the row covered and plants growing well; and $5=$ no interruption in the in the row and plants uniformly growing well.

${ }^{\mathrm{b}}$ Canopy width $(\mathrm{cm})$ was measured at six arbitrarily chosen points in each plot at 32 days after planting (DAP) in 2014 and 56 DAP at each location in 2015. Since time of measurement differed by over three weeks between years at the Lang Farm, results from the two years are presented independently.

${ }^{\mathrm{c}}$ Final plant population was determined immediately after plots were inverted by counting taproots of inverted plants.

${ }^{\mathrm{d}}$ Estimated relative treatment effects (0-1.0), and the respective 95\% confidence intervals (CI) were calculated by the method of Shah and Madden (2004) from nonparametric ranks-based analysis using the LD_CI SAS macro. Two relative treatment effects are considered different if they each lie outside the confidence interval of the other.

e Seeds were treated with a mixture of azoxystrobin $0.128 \mathrm{~g} / \mathrm{kg}$ of seed, fludioxanil $0.008 \mathrm{~g} / \mathrm{kg}$ of seed, and mefenoxam $0.0016 \mathrm{~g} / \mathrm{kg}$ of seed applied as Dynasty PD.

${ }^{\mathrm{f}}$ There was no significant treatment effect $(\mathrm{P}>0.05)$; therefore no LSD was calculated. 
width measurements at the Lang Farm were made later in 2015 than in 2014 , this variable was analyzed independently for each year. At both locations in 2015, immediately after plants were inverted, number of plants were counted for each plot, and converted to plants $/ \mathrm{m}$ of row, reported as the final population.

Leaf spot assessment. Leaf spot was assessed visually using the ordinal Florida 1-10 leaf spot severity scale where $1=$ no disease, $0 \%$ defoliation, and $10=100 \%$ defoliation, plants dead, killed by leaf spot (Chiteka et al. 1988). In 2014, leaf spot assessments were made 135 DAP at Gibbs Farm and 142 DAP at Lang Farm. In 2015, leaf spot ratings were made 105, 112, 119, 126, 133, 140, and 147 DAP at the Gibbs Farm and 63, 70, 77, 84, 91, 98, 105, 112, 119, 126, 133, and 140 DAP at the Lang Farm. In 2015, area under the disease progress curve (AUDPC) was calculated as described by Shaner and Finney (1977) and area under the disease stair (AUDPS) was calculated as described by Simko and Piepho (2012).

Canopy reflectance measurement. Canopy reflectance was measured 147 DAP in 2015 at the Gibbs Farm and 140 DAP in both years at the Lang Farm. An active sensor reflectance meter (Crop Circle model ACS-210, Holland Scientific, Lincoln, NE), which simultaneously measures canopy reflectance in the visible (VIS, centered at $650 \mathrm{~nm}$ ) and near infrared (NIR, centered at $880 \mathrm{~nm}$ ) portions of the light spectrum, was used for these measurements. For each plot, a vegetation index, presented as the normalized difference vegetation index (NDVI), was calculated using the formula:

$$
\mathrm{NDVI}=(r e f \mathrm{NIR}-\operatorname{ref} \mathrm{VIS}) /(\operatorname{ref} \mathrm{NIR}+\operatorname{ref} \mathrm{VIS})
$$

where refNIR and refVIS are reflectance measurements for the near infrared and visible portions of the light spectrum, respectively.

For each evaluation, the sensor was carried manually and positioned directly over the center of the row in the nadir view at a distance of approximately $1.0 \mathrm{~m}$ above the plant canopy. Scans were made of the entire length of both rows of each plot by walking at a speed of approximately $0.9 \mathrm{~m} / \mathrm{sec}$. Sensor readings were recorded
10 times per second, resulting in an average of approximately 125 individual sensor readings per plot. The final output of the sensor was a pseudo-reflectance value for both NIR and VIS bands and the calculated NDVI. The mean of sensor readings for NDVI was calculated for each plot, which was used for analysis and genotype comparisons.

Yield and grade determination. All plots were dug and inverted at 147 DAP at Gibbs Farm in both years, and 140 and 145 DAP at Lang Farm in 2014 and 2015, respectively. Peanut pods were harvested mechanically 7 to 11 days after inverting, and pod yields were determined by weighing harvested pods after they were dried and adjusted to $10 \%(\mathrm{w} / \mathrm{w})$ moisture.

One 1,000-g sample of harvested pods was collected from each plot of two replications in 2014 and all replications in 2015 for grade determination from trials at the Gibbs Farm, and from all plots from the Lang Farm in 2015. In 2014 at the Lang Farm, a similar sample was collected from the bulked yield from all replications for each genotype and seed treatment combination. The samples were cleaned, and non-pod materials were weighed. A 500-g sample of cleaned pods was shelled using commercial shelling equipment for grading. Kernels were classified as sound, immature, or damaged, and the kernels in each category were weighed. The percentages of the $500 \mathrm{-g}$ sample represented by sound mature, immature, and damaged kernels were determined according to official Federal-State Inspection Service methods (USDA-AMS 1997). Percent total sound mature kernels (\% TSMK) was calculated as the percentage of the $500-\mathrm{g}$ sample that was sound mature kernels.

Data analysis. Data were analyzed using SAS v.9.4 software (SAS Institute, Cary, NC). For all variables except vigor ratings in 2014 and final leaf spot severity ratings in both years, a mixed models procedure was used with maximum likelihood estimation of variance components (Proc Mixed). The Satterthwaite method was used for computing the denominator degrees of freedom ("ddfm=satterth" in the model statement). Since trials at the Gibbs Farm and the Lang

Table 2. Median, mean rank $\left(\bar{R}_{i}.\right)$, and estimated relative treatment effects $\left(\hat{p}_{i}\right)$ with $95 \%$ confidence intervals $(\mathrm{CI})$ for final leaf spot ratings for new peanut breeding lines and cultivar standards, The University of Georgia Lang Farm and Gibbs Farm, Tifton, GA, 2014 and 2015

\begin{tabular}{|c|c|c|c|c|c|c|c|c|}
\hline \multirow[b]{3}{*}{ Genotype } & \multicolumn{8}{|c|}{ Final leaf spot severity ratinga } \\
\hline & \multicolumn{4}{|c|}{ Lang } & \multicolumn{4}{|c|}{ Gibbs } \\
\hline & Median rating & $\overline{\boldsymbol{R}}_{\boldsymbol{i}}$ & $\hat{p}_{i}^{\mathbf{b}}$ & $95 \%$ CI for $\hat{p}_{i}$ & Median rating & $\overline{\boldsymbol{R}}_{\boldsymbol{i}}$ & $\hat{p}_{i}^{\mathbf{b}}$ & $95 \%$ CI for $\hat{p}_{i}$ \\
\hline \multicolumn{9}{|l|}{2014} \\
\hline GA072523 & 5.8 & 29 & 0.52 & $0.33,0.71$ & 4.0 & 33 & 0.65 & $0.48,0.81$ \\
\hline GA072523-1 & 5.5 & 29 & 0.52 & $0.35,0.68$ & 4.0 & 29 & 0.57 & $0.43,0.71$ \\
\hline GA072523-3 & 5.5 & 27 & 0.47 & $0.32,0.63$ & 5.0 & 37 & 0.72 & $0.56,0.89$ \\
\hline GA072523-4 & 5.3 & 23 & 0.40 & $0.22,0.62$ & 5.0 & 38 & 0.75 & $0.56,0.93$ \\
\hline GA072523-7 & 5.5 & 24 & 0.43 & $0.28,0.60$ & 3.0 & 14 & 0.27 & $0.11,0.44$ \\
\hline GA072523-8 & 5.0 & 19 & 0.34 & $0.17,0.60$ & 4.0 & 29 & 0.57 & $0.43,0.72$ \\
\hline GA072523-9 & 5.0 & 20 & 0.35 & $0.16,0.62$ & 3.0 & 14 & 0.27 & $0.11,0.44$ \\
\hline GA072523-10 & 5.5 & 26 & 0.46 & $0.24,0.70$ & 4.0 & 29 & 0.57 & $0.43,0.72$ \\
\hline GA072523-11 & 4.8 & 14 & 0.25 & $0.10,0.55$ & 4.0 & 25 & 0.50 & $0.28,0.71$ \\
\hline Georgia-12Y & 7.5 & 47 & 0.84 & $0.72,0.90$ & 3.0 & 7 & 0.12 & $0.08,0.16$ \\
\hline Georgia-06G & 8.8 & 51 & 0.91 & $0.70,0.95$ & - & - & - & - \\
\hline \multicolumn{9}{|l|}{2015} \\
\hline GA072523 & 6.0 & 32 & 0.71 & $0.61,0.78$ & 5.0 & 21 & 0.68 & $0.41,0.94$ \\
\hline GA072523-1 & 5.0 & 17 & 0.37 & $0.24,0.53$ & 4.0 & 10 & 0.30 & $0.08,0.52$ \\
\hline GA072523-3 & 5.0 & 13 & 0.28 & $0.23,0.35$ & 5.0 & 18 & 0.59 & $0.42,0.77$ \\
\hline GA072523-4 & 5.3 & 22 & 0.48 & $0.29,0.68$ & 5.0 & 17 & 0.56 & $0.09,1.00$ \\
\hline GA072523-7 & 4.8 & 8 & 0.16 & $0.08,0.34$ & 3.5 & 9 & 0.27 & $0.11,0.43$ \\
\hline GA072523-8 & 5.3 & 20 & 0.45 & $0.29,0.62$ & 4.0 & 11 & 0.34 & $0.19,0.50$ \\
\hline GA072523-9 & 5.3 & 20 & 0.45 & $0.29,0.62$ & 5.0 & 16 & 0.52 & $0.23,0.82$ \\
\hline GA072523-10 & 5.5 & 25 & 0.57 & $0.39,0.72$ & 3.0 & 6 & 0.18 & $0.00,0.39$ \\
\hline GA072523-11 & 5.0 & 10 & 0.22 & $0.14,0.36$ & 5.0 & 20 & 0.64 & $0.42,0.86$ \\
\hline Georgia-12Y & 7.6 & 39 & 0.87 & $0.86,0.87$ & 6.0 & 28 & 0.90 & $0.83,0.97$ \\
\hline Georgia-06G & 9.0 & 42 & 0.95 & $0.91,0.95$ & - & - & - & - \\
\hline
\end{tabular}


Farm differed in the genotypes evaluated, experiments at the two farms were analyzed separately. Data were analyzed across years within each location for variables that were measured similarly in both years. For trials at the Lang Farm, a preliminary factorial (two cultivars $\times$ seed treatment) analysis of the effects of seed treatments was conducted using Proc Mixed for all variables that did not use an ordinal scale. If seed treatment had no effect in either cultivar, data for each cultivar were pooled across seed treatments for the main analysis, and are presented in that form. If there was a significant effect in either cultivar, each combination of cultivar and seeding rate were analyzed as separate genotypes in subsequent analysis, and results are presented that way. Genotype was considered a fixed effect, whereas replication, year, and year*genotype interaction effects were considered random effects. Effects were considered significant when $P \leq 0.05$. Fisher's protected least significant difference (LSD) values were computed using standard errors and t-values of adjusted degrees of freedom from the lsmeans /pdiff option for Proc Mixed.

Since early season vigor ratings at the Lang Farm in 2015 and final leaf spot severity in both years and locations were evaluated using ordinal scales that do not represent continuous scales of measurement, these variables were analyzed nonparametrically based on ranks (Shah and Madden 2004). Each trial was analyzed independently. A preliminary factorial (two cultivars $\times$ seed treatment) analysis of the effects of seed treatment was conducted for vigor ratings and final leaf spot severity ratings at the Lang Farm. If seed treatment had no effect in either cultivar, data for each cultivar were pooled across seed treatments for the main analysis, and are presented in that form. If there was a significant effect in either cultivar, each combination of cultivar and seeding rate were analyzed as separate genotypes in subsequent analysis, and results are presented that way.
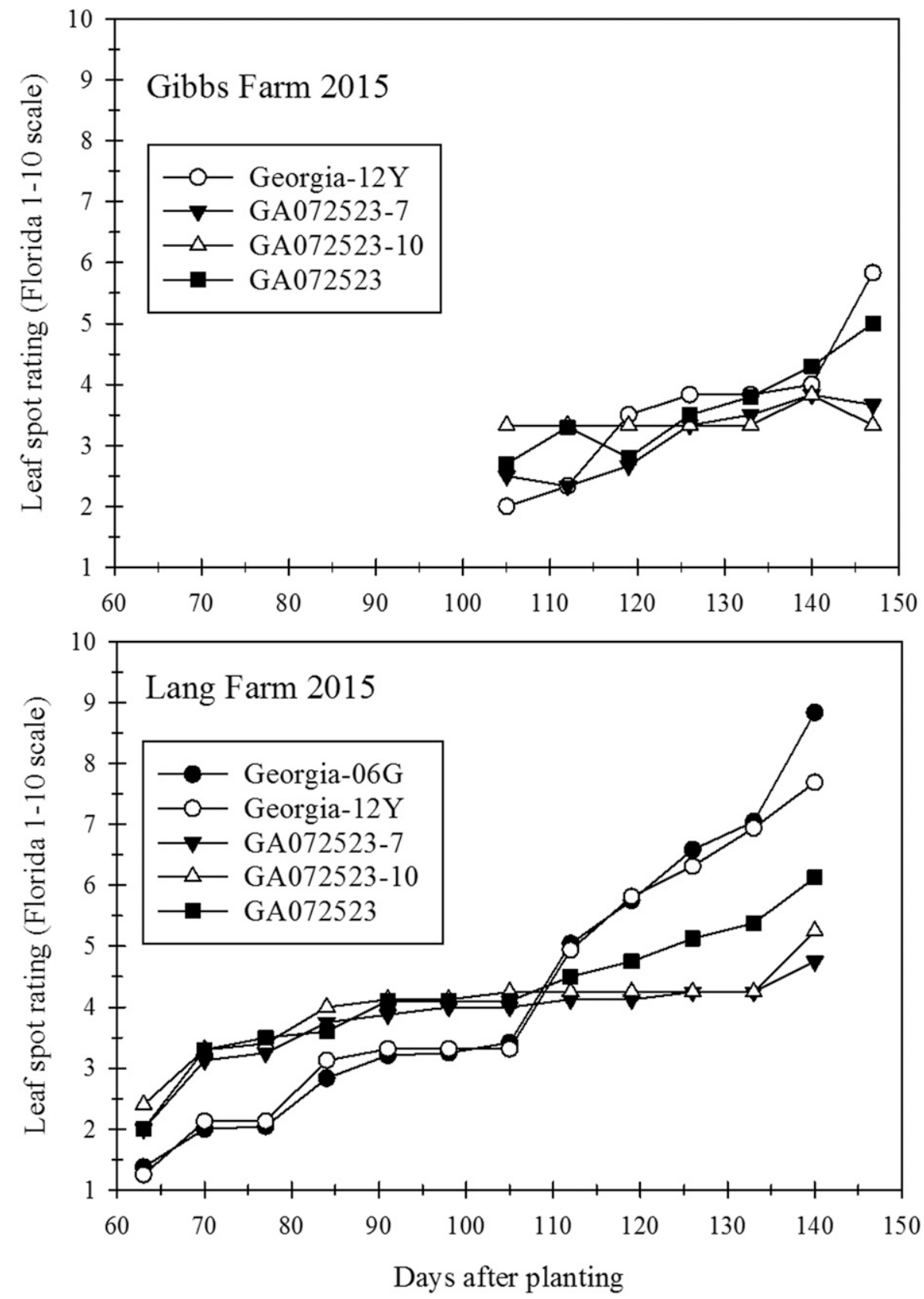

Fig. 1. Effect of peanut genotype on disease progress of late leaf spot, caused by Cercosporidium personatum, at Gibbs Farm and Lang Farm locations, Tifton, GA, in 2015. Leaf spot was assessed visually using the ordinal Florida $1-10$ leaf spot scale where $1=$ no disease, $0 \%$ defoliation, and $10=100 \%$ defoliation, plants dead, killed by leaf spot (Chiteka et al. 1988). Advanced breeding lines GA072523-7 and GA072523-10, two of the more resistant lines evaluated, as well as GA072523, the most susceptible of the breeding lines evaluated, are shown for illustration of disease progression relative to the cultivar standards. 
Relative treatment effects and their respective confidence intervals were calculated using the LD_CI macro for SAS (Brunner et al. 2002; Shah and Madden 2004) and were used to discern differences among the genotypes. Relative treatment effect $\left(\hat{p}_{i}\right)$ is estimated from the mean ranks according to:

$$
\hat{p}_{i}=\frac{1}{N}\left(\bar{R}_{i} \cdot-\frac{1}{2}\right)
$$

where $\bar{R}_{i}$. is the mean rank for the treatment among all observations $(N)$. Relative treatment effects have a range of 0 to 1.0. Two relative treatment effects were considered different if they each lie outside the confidence interval of the other.

Relationship between NDVI and percent defoliation. Regression analysis was used to examine the linear and nonlinear relationships between NDVI and final percent defoliation for each location. Percent defoliation was calculated from Florida 1-10 scale ratings using the formula developed by Li et al. (2012):

$$
\% \text { Defoliation }=\frac{100}{1+e^{-\left(\frac{F L S c-6.0672}{0.7975}\right)}}
$$

where FLSc is the Florida scale value.

Nonlinear regression (Proc NLIN, SAS v.9.4) was used for piecewise regression to examine for the relationship between NDVI and final percent defoliation. Goodness of fit of the piecewise regression was evaluated by calculating the linear correlation coefficient $(R)$ for the correlation between observed versus predicted values of the model.

\section{Results}

Plant vigor and final plant population. At the Lang Farm in 2014, vigor ratings for Georgia-06G were lower with no seed treatment with treated seed (Table 1). Vigor ratings for Georgia-06G with seed treatment were lower than for any other genotype except GA072523-7 (Table 1). Vigor ratings for treated versus nontreated seed were similar for Georgia-12Y, and both were similar to vigor ratings for GA072523-1, GA072523-4, GA072523-8, GA0725239, and GA072523-10 (Table 1). There was no difference in canopy width for treated and untreated seed within either Georgia-06G or Georgia-12Y in either year (Table 1). Canopy width 32 DAP was greater for all breeding lines except GA072523-7 than in nontreated plots of Georgia-06G (Table 1), and greater for GA072523-1, GA072523-4, GA072523-9, and Georgia-12Y than for treated plots of Georgia-06G (Table 1). In 2015, final population was greater for all breeding lines than for Georgia-06G with or without seed treatment (Table 1). In 2015, canopy width at 56 DAP was greater for Georgia-12Y and all breeding lines than for nontreated Georgia$06 \mathrm{G}$, and was similar to or greater than that of treated plots of Georgia-06G in all other genotypes (Table 1). At the Gibbs Farm in 2015, canopy width at 56 DAP ranged from $53.9 \mathrm{~cm}$ in GA072523-7 to $63.7 \mathrm{~cm}$ in GA072523-11, but there was no significant genotype effect (Table 1). In that trial, final plant populations for all breeding lines were similar to those of Georgia-12Y (Table 1).

Leaf spot final leaf spot ratings, AUDPC, AUDPS, and NDVI. Late leaf spot was the predominant $(>95 \%)$ foliar disease at both locations in both years. Disease ratings were greater in the Lang Farm location than the Gibbs Farm in both years, with final median leaf spot scale ratings over 7.0 for Georgia-12Y at the Lang Farm, and median final disease ratings of 6.0 or lower for all genotypes at the Gibbs Farm in both years (Table 2). In 2015, epidemics were evident by 70 DAP at the Lang Farm, whereas similar levels of leaf spot were not observed until 100 DAP at the Gibbs Farm (Fig. 1) There were no differences in final leaf spot ratings, AUDPC, AUDPS, or NDVI in 2015 between seed treatments for either Georgia-06G or Georgia$12 Y$ (data not shown).

Based on relative treatment effects, leaf spot ratings at the Lang Farm were similar for Georgia-06G and Georgia-12Y in 2014, but were higher in Georgia-06G than in Georgia-12Y in 2015 (Table 2). Leaf spot ratings for Georgia-06G and Georgia-12Y were higher than for any of the new breeding lines in both years. There were no differences among the nine breeding lines in 2014 (Table 2). In 2015, GA072523-3, GA072523-7, and GA072523-11 had lower relative treatment effect values than any of the other breeding lines (Table 2). At the Gibbs Farm in 2014, final leaf spot ratings were lower in Georgia-12Y, GA072523-7, and GA0725239 than in any other genotype (Table 2). Final leaf spot ratings did not differ among any of the other breeding lines (Table 2). In 2015, all breeding lines except GA072523 and GA072523-4 had final leaf spot ratings that were lower than that of Georgia-12Y (Table 2).

In 2015 at the Lang Farm, AUDPC and AUDPS were similar for Georgia-06G and Georgia-12Y (Table 3). AUDPC and AUDPS values for GA072523-7, GA072523-8, GA072523-9, and GA072523-11 were lower than for either Georgia-06G or Georgia-12Y, and AUDPS values for GA072523-1, GA072523-3, GA072523-4, and GA07252310 were also lower than for either of the cultivars (Table 3 ). There were no significant genotype effects on either AUDPC or AUDPS at the Gibbs Farm (Table 3).

At the Lang Farm in 2015, NDVI was lower for Georgia-06G than in any other genotype (Table 3). NDVI values were lower for Georgia$12 \mathrm{Y}$ than for any other genotype except Georgia-06G. Among the other breeding lines, NVDI values for GA072523-7 and GA072523-11 were higher than those of GA072523 (Table 3). At the Gibbs Farm, NDVI ranged from 0.777 in GA072523 to 0.805 in GA072523-7, but there were no differences among genotypes (Table 3 ).

Yield and grade. At the Lang Farm, there were no significant differences in yield or \% TSMK for seed treatment in Georgia-06G or Georgia-12Y. Across years, all of the breeding lines except GA07252311 had yields that were greater than those of Georgia-06G and similar to those of Georgia-12Y (Table 4). Across years at the Gibbs Farm, there was no significant genotype effect on yield (Table 4).

At the Lang Farm in 2014, \% TSMK values from bulked samples ranged from 73.0\% (Georgia-12Y) to 78.9 (GA072523-1). However, significance of differences among means was not estimable. In 2015, \% TSMK, was higher for Georgia-06G than for GA072523, GA0725238, GA072523-10, and GA072523-11 (Table 4), and did not differ among other entries (Table 4). Across years at the Gibbs Farm, \%TSMK was higher for all breeding lines except GA072523-7 than for Georgia-12Y (Table 4).

Table 3. Mean area under the disease progress curve (AUDPC), area under the disease progress stairs (AUDPS), and normalized difference vegetation index (NDVI) values for new peanut breeding lines and cultivar standards, The University of Georgia Lang Farm and Gibbs Farm, Tifton, GA, 2014 and

\begin{tabular}{|c|c|c|c|c|c|c|}
\hline \multirow[b]{3}{*}{ Genotype } & \multicolumn{2}{|c|}{ AUDPCa } & \multicolumn{2}{|c|}{ AUDPS $^{\mathbf{b}}$} & \multicolumn{2}{|c|}{ NDVI $^{c}$} \\
\hline & 2015 & $\overline{2015}$ & 2015 & 2015 & 2014-15 & 2015 \\
\hline & Lang & $\overline{\text { Gibbs }}$ & Lang & Gibbs & Lang & Gibbs \\
\hline GA072523 & 363 & 152 & 391 & 179 & 0.714 & 0.777 \\
\hline GA072523-1 & 357 & 138 & 382 & 160 & 0.739 & 0.796 \\
\hline GA072523-3 & 357 & 155 & 382 & 183 & 0.726 & 0.792 \\
\hline GA072523-4 & 362 & 147 & 387 & 174 & 0.737 & 0.799 \\
\hline GA072523-7 & 324 & 131 & 348 & 153 & 0.750 & 0.805 \\
\hline GA072523-8 & 337 & 143 & 364 & 166 & 0.729 & 0.799 \\
\hline GA072523-9 & 334 & 145 & 361 & 172 & 0.731 & 0.800 \\
\hline GA072523-10 & 363 & 148 & 390 & 172 & 0.731 & 0.802 \\
\hline GA072523-11 & 326 & 142 & 350 & 170 & 0.750 & 0.801 \\
\hline Georgia-12Y & 367 & 150 & 398 & 177 & 0.686 & 0.802 \\
\hline Georgia-06G & 370 & - & 405 & - & 0.588 & - \\
\hline $\operatorname{LSD}(P=0.05)$ & 14 & $n s^{d}$ & 15 & $n s^{d}$ & 0.028 & $\mathrm{~ns}^{\mathrm{d}}$ \\
\hline Mean square error & 189 & 113 & 212 & 160 & 0.0008 & 0.0002 \\
\hline
\end{tabular}
2015

${ }^{a}$ Area under the disease progress curve was calculated by the method of Shaner and Finney (1977) from nine evaluations at the Lang Farm and seven evaluations at the Gibbs using the Florida 1-10 leaf spot severity scale.

b Area under the disease progress curve stairs was calculated by the method of Simko and Piepho (2012) from nine evaluations at the Lang Farm and seven evaluations at the Gibbs using the Florida 1-10 leaf spot severity scale.

${ }^{c}$ Normalized difference vegetation index measured 140 DAP in each of 2014 and 2015 at Lang farm and 147 DAP in 2015 at the Gibbs farm. Values for the Lang farm trials are from data pooled across 2014 and 2015.

d There was no significant genotype effect; therefore, no LSD was calculated. 
Relationship between defoliation and NDVI. Across years and genotypes at the Lang Farm, the relationship between NDVI and final percent defoliation was described by a two linear sector piecewise regression with a break point at approximately $88.7 \%$ defoliation (Fig. 2). NDVI declined more rapidly after that point as defoliation increased. There was no significant regression for NDVI versus percent defoliation for the Gibbs Farm trial in 2015 (Fig. 2).

\section{Discussion}

For organic peanut production, cultivars are needed that can produce good yields without fungicides. However, reports of evaluations of peanut genotypes primarily for use in organic production in the southeastern U.S. have been limited (Branch and Culbreath 2013; Cantonwine et al. 2011; Holbrook and Culbreath 2008; Wann et al. 2011), and only one runner-type peanut cultivar, Georganic, has been released primarily for use in organic production (Holbrook and Culbreath 2008). Wann et al. (2011) reported that runner-type cultivars Tifguard and Florida- 07 produced higher yield than Georganic when grown without fungicide applications, even when defoliation caused by late leaf spot diseases was lower in Georganic. Branch and Culbreath (2013) reported that several new cultivars and breeding lines produced higher yields than Georganic in trials without fungicides or insecticides. In one year of that study, they reported that GA072531, which was released as cultivar Georgia-12Y (Branch 2013), produced greater yield than Georganic, Tifguard, or Florida-07, despite having more severe leaf spot than Georganic (Branch and Culbreath 2013). Neither of those studies included Georgia-06G, the predominant cultivar currently grown in conventional production in the southeastern U.S. Results from this study indicate that the cultivar Georgia-12Y and several of advanced breeding lines have better potential for use in organic programs and limited fungicide use programs than Georgia-06G.

Based on final leaf spot ratings, several of the breeding lines evaluated in this study are more resistant to $C$. personatum than either Georgia-06G or Georgia-12Y. With median final leaf spot ratings in the Lang Farm trials of 4.8 or higher, it is evident that these breeding lines have only partial resistance to $C$. personatum. Although all of the breeding lines had lower final leaf spot ratings than Georgia06G or Georgia-12Y in 2015, epidemics were evident earlier in most of the lines than in Georgia-06G or Georgia-12Y. Likely, this was the

Table 4. Means for pod yield and percent total sound mature kernels (TSMK) for new peanut breeding lines and standard cultivars evaluated at The University of Georgia, Lang Farm and Gibbs Farm, Tifton, 2014-15

\begin{tabular}{|c|c|c|c|c|c|}
\hline \multirow[b]{3}{*}{ Genotype } & \multicolumn{2}{|c|}{ Pod yield (kg/ha) } & \multicolumn{3}{|c|}{$\%$ TSMK $^{\mathbf{a}}$} \\
\hline & Lang & Gibbs & Lang & Lang & Gibbs \\
\hline & $2014-2015^{b}$ & $2014-2015^{b}$ & $\overline{2014}$ & $\overline{2015}$ & $2014-2015^{b}$ \\
\hline GA072523 & 6,380 & 5,334 & 74.0 & 68.9 & 77.1 \\
\hline GA072523-1 & 6,901 & 5,792 & 78.9 & 70.4 & 77.6 \\
\hline GA072523-3 & 6,743 & 5,796 & 75.6 & 72.5 & 77.5 \\
\hline GA072523-4 & 6,497 & 5,587 & 76.6 & 70.7 & 76.8 \\
\hline GA072523-7 & 6,555 & 5,519 & 76.0 & 70.4 & 76.4 \\
\hline GA072523-8 & 6,323 & 5,956 & 76.8 & 69.2 & 77.4 \\
\hline GA072523-9 & 7,078 & 5,874 & 76.2 & 70.7 & 77.8 \\
\hline GA072523-10 & 6,898 & 5,668 & 77.4 & 69.5 & 77.4 \\
\hline GA072523-11 & 6,093 & 5,668 & 76.3 & 67.9 & 78.6 \\
\hline Georgia-12Y & 6,792 & 6,133 & 73.0 & 72.3 & 75.2 \\
\hline Georgia-06G & 5,564 & - & 78.0 & 73.9 & - \\
\hline $\operatorname{LSD}(P=0.05)$ & 646 & $n s^{c}$ & $\mathrm{na}^{\mathrm{d}}$ & 4.0 & 1.4 \\
\hline Mean square error & 323,614 & 465,931 & na & 8.0 & 1.3 \\
\hline
\end{tabular}

a Percentage of total percent sound mature kernels of a $500 \mathrm{~g}$ sample of inshell peanuts, after drying to $10 \%$ moisture.

${ }^{\mathrm{b}}$ Data were analyzed pooled across the two years.

${ }^{c}$ There was no significant treatment effect $(P>0.05)$. Therefore, no LSD was calculated.

${ }^{d}$ Values presented for 2014 were from one sample taken from the bulked yield from all replications of each genotype. Therefore, analysis of genotype effects was not possible. reason several breeding lines had AUDPC values that did not differ from that of Georgia-06G. AUDPS for GA072523 and Georgia-12Y did not differ from that of Georgia-06G at the Lang Farm, and there were no differences among entries for either AUDPC or AUDPS at the Gibbs Farm. Use of either AUDPC or AUDPS solely for comparison of genotypes could result in erroneous conclusions regarding best lines for use in managing leaf spot based on severity at the end of the season. Additional work is needed to characterize the effects of these breeding lines on leaf spot epidemics in the field, and to determine which components of resistance are responsible for the lower final leaf spot levels observed in this study.

Georgia-06G has shown some tolerance to defoliation by leaf spot diseases (Navia Gine 2012). Although direct comparisons are not possible, yields of Georgia-06G in this study were similar to the higher yields reported by Branch and Culbreath (2013) or Wann et al. (2011) in trials without fungicides for disease control. Similarly, direct comparisons cannot be made, but for perspective, the average yield for conventional peanuts for Georgia in 2015 was $4,928 \mathrm{~kg} / \mathrm{ha}$, the second highest average yield on record (Rabinowitz and Smith 2017). Although final leaf spot ratings for Georgia-12Y were lower than those of Georgia-06G in 2015, Georgia-12Y had high levels of defoliation in both years at the Lang Farm. However, Georgia-12Y had higher yield than that of Georgia-06G, and yields that were similar to those of other breeding lines for which leaf spot severity was lower. This suggests that tolerance to defoliation by late leaf spot may be a factor in this cultivar. Regardless of the factors responsible for higher yield production, these results indicate that Georgia-12Y and most of the breeding lines examined have better yield potential than that of Georgia-06G when grown without fungicides. Three lines, GA072512-1, GA072512-9, and GA072512-10, were selected based on combinations of yield, grade, and leaf spot response for further evaluation. Trials are in progress in which these breeding lines and Georgia-12Y are being combined with earlier planting dates, which may allow avoiding severe leaf spot epidemics (Kemerait et al. 2016).

Breeding lines GA072512-1, GA072512-9, and GA072512-10 in particular show promise for production without fungicides, but this study did not address whether yield might be increased with applications of either organically acceptable or conventional fungicides for leaf spot control. Experiments are planned to determine whether application of acceptable fungicides are warranted for organic production. In addition, these lines and Georgia-12Y may have potential for reducing fungicide applications needed for leaf spot control in conventional production as well. Experiments addressing that possibility are also planned.

In the absence of tomato spotted wilt, runner-type peanut plants often can compensate for sparse plant populations with minimal reduction in yield. Knauft et al. (1981) reported no reduction in yield for the cultivar Florunner for plant populations of 9.8 and 6.6 plants $/ \mathrm{m}$ of row, and no difference in yield for three genotypes across a range of 9.8 to 3.3 plants $/ \mathrm{m}$ of row. However, plant population affects severity of tomato spotted wilt in peanut, and establishing plant populations of 13.1 plants $/ \mathrm{m}$ or greater are recommended to minimize damage by that disease (Culbreath and Srinivasan 2011). Stand establishment and early season vigor can be more critical in organic production systems. In addition to affecting severity of tomato spotted wilt, plant population can be a critical factor in weed management (Wann et al. 2011). Wann et al. (2011) reported that sparse stands with some genotypes resulted in complete loss of the plots to weeds even with mechanical cultivation, whereas the same cultivation methods provided weed control adequate to allow harvest with genotypes that had greater plant populations and covered the area between rows was covered more rapidly.

Few studies have addressed stand establishment and early season vigor of peanut genotypes for organic production. Cantonwine et al. (2011) reported that multiple genotypes had better seedling establishment rates and produced greater biomass than the cultivar Georganic but did not report on disease susceptibility or pod yield of those lines. The field experiments at the Lang Farm in this study indicate that Georgia-12Y and several breeding lines show better potential for 
stand establishment and more rapid ground coverage than the current standard cultivar Georgia-06G. Based on early season vigor ratings in 2014, final plant populations in 2015, and canopy width measurements in both years, Georgia-12Y and multiple breeding lines with no seed treatment had greater populations and vigor measurements than Georgia-06G with standard seed treatment. Rapid coverage of the ground between rows should help with weed competition in organic production where conventional herbicides are not allowed. In this study, conventional herbicide regimes were used for weed control, so the effects on weed control were not discernable. However, studies are in progress in which Georgia-06G, Georgia-12Y, and selected other lines are being compared for weed competition and response to various cultivation methods for weed control without herbicides. Stand establishment and early season vigor in Georgia$12 \mathrm{Y}$ and the breeding lines are especially noteworthy, considering that several cultivars released previously with excellent combinations of resistance to TSWV and leaf spot pathogens had major problems with stand establishment, even with conventional seed treatments (Thornton et al. 2011). Additional work is needed to characterize what genetic or physiological factors are responsible for the apparent increased vigor observed in Georgia-12Y and these breeding lines compared with Georgia-06G.

Although the breeding lines included in this study have similar parentage, there was some variation in their effects on late leaf spot. However, differences in leaf spot ratings among the breeding lines were small relative to the difference between any of the lines and Georgia-06G. There was also some variation in yield among the breeding lines, but there was no difference in yield that corresponded with difference in leaf spot ratings. All but one of the breeding lines had yields that were greater than that of Georgia-06G. Effects of the breeding lines on both leaf spot and yield relative to Georgia-06G were consistent across two years in this study. However, this study did not characterize the relative disease resistance or yield potential of these lines across a range of locations and environments in which they might potentially be grown. In particular, characterization is needed in locations where early leaf spot is the predominant foliar disease. Very little early leaf spot was observed in any trial of this study. Although both Georgia-06 and Georgia-12Y are susceptible to early leaf spot, the response of the new breeding lines is not known.

Canopy reflectance has been used as an indication of leaf spot severity in peanut (Aquino et al. 1992; Navia Gine 2012; Nutter et al. 1990; Nutter and Littrell 1996). Use of canopy reflectance represents a more objective assessment than visual assessments, and one which could help minimize variability among evaluators. Although reflectance measurements in this study were obtained with a hand-carried instrument, there is potential to obtain such measurements with remote sensing. Nonetheless, there are limitations to the use of reflectance for leaf spot assessment. Navia Gine (2012) reported correlation between NDVI and defoliation caused by early leaf spot within cultivars, but NDVI values were not a good predictor of relative severity of leaf spot when defoliation levels were low. These results likewise indicated that NDVI is not useful for evaluating late leaf spot before defoliation is evident. In 2015, there were no differences among genotypes for NDVI at the Gibbs Farm, when defoliation levels represented by the highest leaf spot ratings were less than $50 \%$ (below 6.0 on the Florida 1-10 scale, Chiteka et al. 1988). In that trial, differences among entries were discernable based on visual ratings. However, results from this study indicate that NDVI may be useful for comparing leaf spot severity in different genotypes if there are differences in defoliation. Across years at the Lang Farm, with severe epidemics and a wide range of defoliation, NDVI values gave similar separation among the genotypes as visual final disease assessment with the Florida 1-10 scale. All lines had higher NDVI measurements and lower final disease ratings than Georgia-06G. However, rate of decline of NDVI with increasing levels of defoliation was greater with levels of defoliation above $88 \%$ than it was with lower levels. Genotypes may also differ in reflectance even with little or no leaf spot (Navia Gine 2012), so making conclusions about resistance based solely on NDVI measurements is not advised. However, such measurements show potential for use in characterizing response to leaf spot if epidemics are severe enough to cause defoliation and appropriate confirmation of disease levels is made. To the best of our knowledge, this the first report of use of NDVI measurements for comparison of peanut genotype responses to late leaf spot. Studies are in progress in which reflectance measurements

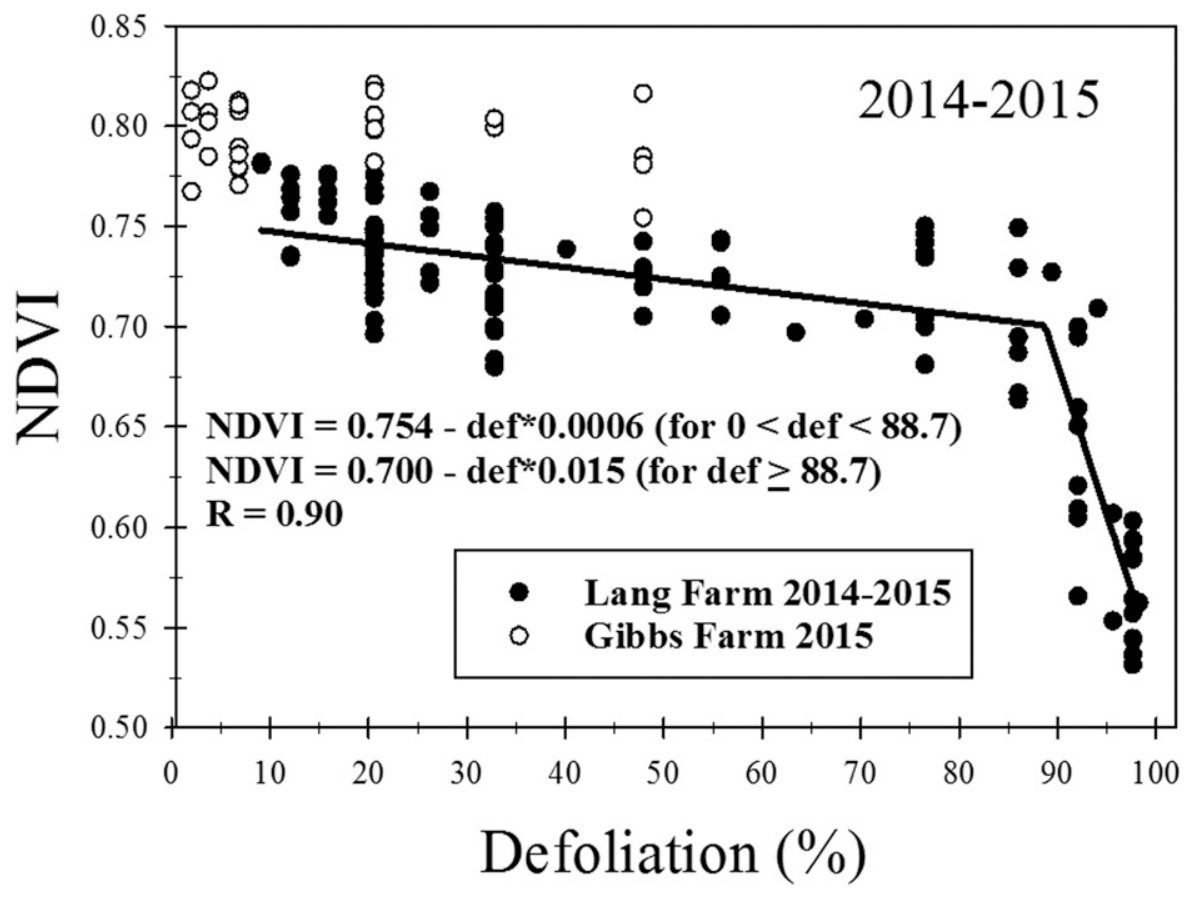

Fig. 2. Relationship between normalized difference vegetation index (NDVI) and visually assessed percent defoliation (def) caused by Cercosporidium personatum in peanut at the Lang Farm location in 2014 and 2015 and the Gibbs Farm location in 2015, Tifton, GA. For the Lang Farm, NDVI decreased with increasing percent defoliation as described by piecewise regression with two linear segments with a breakpoint at $88.7 \%$ defoliation. $R$ is the correlation coefficient $(0-1.0)$ for the linear correlation between observed versus predicted values of the model. There was no significant regression $(P>0.36)$ for the Gibbs Farm trial. 
and visual assessments over time are being compared in some of these same breeding lines.

This study has implications for areas in which growers do not have access to fungicides or where fungicides are cost prohibitive, in addition to production situations such as organic production where fungicide use is limited or not acceptable. These results indicate that peanut genotypes with the combination of the potential for good stand establishment and early season vigor with resistance or tolerance to late leaf spot and good yield potential are available. These breeding lines show potential for use in organic production without any fungicide, and could allow reduction in fungicides needed in conventional production. Although none of the breeding lines had grades as high as Georgia-06G in 2015, most were comparable to Georgia-12Y. Considering the yield potential without fungicides, grades obtained in most of the lines were likely adequate. In addition, these results indicate that the use of NDVI has potential for assessing leaf spot severity in peanut genotype evaluations for leaf spot resistance in trials where defoliation in more susceptible genotypes is over $50 \%$.

\section{Acknowledgments}

Support for this research was funded in part by the National Peanut Board, the Georgia Agricultural Commodity Commission for Peanuts, and Georgia Foundation Seed. We also acknowledge the United States Department of AgricultureNational Institute of Food and Agriculture, Hatch Project GEO-00691. The authors thank Mike Heath, Ron Hooks, Matthew Wiggins, Kyle Parris, Neal Roberson, and Harvey Kendrick for their help in this project.

\section{Literature Cited}

Aquino, V. M., Shokes, F. M., Berger, R. D., Gorbet, D. W., and Kucharek, T. A. 1992. Relationships among late leafspot, healthy leaf area duration, canopy reflectance, and pod yield of peanut. Phytopathology 82:546-552.

Branch, W. D. 1994. Registration of 'Georgia Browne' peanut. Crop Sci. 34: 1125-1126.

Branch, W. D. 2006. Registration of 'Georgia-05E' peanut. Crop Sci. 46:2305. Branch, W. D. 2007. Registration of 'Georgia-06G' peanut. J. Plant Regist. 1:120. Branch, W. D. 2013. Registration of 'Georgia-12Y' peanut. J. Plant Regist. 7:151-153. Branch, W. D., and Culbreath, A. K. 2008. Disease and insect assessment of candidate cultivars for potential use in organic peanut production. Peanut Sci. 35:61-66.

Branch, W. D., and Culbreath, A. K. 2013. Yield performance and pest resistance among peanut genotypes when grown without fungicides or insecticides. Crop Prot. 52:22-25.

Brunner, E., Domhof, S., and Langer, F. 2002. Nonparametric Analysis of Longitudinal Data in Factorial Experiments. John Wiley \& Sons, New York.

Cantonwine, E. G., Culbreath, A. K., Shew, B. B., and Boudreau, M. A. 2008. Efficacy of organically acceptable fungicides for management of early and late leaf spot of peanut. Online. Plant Health Prog. doi:10.1094/PHP-2008-0317-03-RS

Cantonwine, E. G., Holbrook, C. C., Culbreath, A. K., Tubbs, R. S., and Boudreau, M. A. 2011. Genetic and seed treatment effects in organic peanut. Peanut Sci. 38:115-121.

Chiteka, Z. A., Gorbet, D. W., Shokes, F. M., Kucharek, T. A., and Knauft, D. A. 1988. Components of resistance to late leafspot in peanut. I. Levels and variability-implications for selection. Peanut Sci. 15:25-30.
Culbreath, A. K., Selph, A. C., Williams, B. W., Kemerait, R. C. J., Srinivasan, R. Abney, M. R., Tillman, B. L., Hollbrook, C. C., and Branch, W. D. 2016. Effects of new field resistant cultivars and in-furrow applications of phorate insecticide on tomato spotted wilt of peanut. Crop Prot. 81:70-75.

Culbreath, A. K., and Srinivasan, R. 2011. Epidemiology of spotted wilt disease of peanut caused by Tomato spotted wilt virus in the southeastern U.S. Virus Res. 159:101-109.

Holbrook, C. C., and Culbreath, A. K. 2008. Registration of 'Georganic' peanut. J. Plant Regist. 2:17.

Kemerait, R., Culbreath, A., Prostko, E., Brenneman, T., Smith, A., Tubbs, S., Srinivasan, R., Abney, M., Monfort, S., Tillman, B., Dufault, N., Rowland, D., Mulvaney, M., Hagan, A., Sarver, J., Anco, D., and Smith, N. 2016. Peanut Rx: Minimizing diseases of peanut in the southeastern United States. Pages 47-62 in: 2016 Peanut Production Update. W. S. Monfort, ed. University of Georgia Cooperative Extension Publication CSS-12-0130, Athens, GA.

Knauft, D. A., Gorbet, D. W., and Norden, A. J. 1988. Yield and market quality of seven peanut genotypes as affected by leafspot disease and harvest date. Peanut Sci. 15:9-13.

Knauft, D. A., Norden, A. J., and Beninati, N. F. 1981. Effects of intrarow spacing on yield and market quality of peanut (Arachis hypogaea L.) genotypes. Peanut Sci. 8:110-112.

Langston, D. B. 2009. 2008 Georgia Plant Disease Loss Estimates. Univ. Georgia Coop. Ext. Annual Publication 102-1. Athens, GA.

Li, Y., Chen, C. Y., Knapp, S. J., Culbreath, A. K., Holbrook, C. C., and Guo, B. 2012. Variability in field response of peanut genotypes from the U.S. and China to Tomato spotted wilt virus and leaf spots. Peanut Sci. 39:30-37.

Navia Gine, P. A. 2012. Characterization of the Relationship between Leaf Spot Severity and Yield in New Peanut Runner-Type Cultivars and Effects of New Peanut Genotypes on Leaf Spot Epidemics. M.S. thesis, University of Georgia, Athens, GA.

Nutter, F. W., Jr., Brenneman, T. B., and Littrell, R. H. 1990. Utilization of a multispectral radiometer to evaluate fungicide efficacy to control late leaf spot in peanut. Phytopathology 80:102-108.

Nutter, F. W., Jr., and Littrell, R. H. 1996. Relationships between defoliation, canopy reflectance and pod yield in the peanut-late leafspot pathosystem. Crop Prot. 15:135-142.

Rabinowitz, A. N., and Smith, A. R. 2017. Peanut outlook and cost analysis. Pages 60-67 in: 2017 Peanut Production Update. W. S. Monfort, ed. University of Georgia Cooperative Extension Publication CSS-12-0130, Athens, GA.

Shah, D. A., and Madden, L. V. 2004. Nonparametric analysis of ordinal data in designed factorial experiments. Phytopathology 94:33-43.

Shaner, G., and Finney, R. E. 1977. The effect of nitrogen fertilization on the expression of slow-mildewing resistance in Knox wheat. Phytopathology 67: 1051-1056.

Simko, I., and Piepho, H.-P. 2012. The area under the disease progress stairs: calculation, advantage, and application. Phytopathology 102:381-389.

Teare, I. D., Littrell, R. H., Gorbet, D. W., and Shokes, F. M. 1984. Peanut growth responses to different levels of leafspot. Agron. J. 76:103-106.

Thornton, S., Gallo, M., and Tillman, B. 2011. Determining the relationship between field emergence and late leaf spot resistance in peanut. Proc. Am. Peanut Res. Educ. Soc. 43:39 (abstract).

USDA-AMS. 1997. United States standards for grades of shelled runner type peanuts. In http://www.ams.usda.gov/AMSv1.0/getfile?dDocName=StelPRDC505496 (verified 22 February 2012): USDA Agric. Marketing Serv., Washington, D.C.

Wann, D. Q., Tubbs, R. S., and Culbreath, A. K. 2011. Genotype and approved fungicide evaluation for reducing leaf spot diseases in organically-managed peanut. Online. Plant Health Prog. doi:10.1094/PHP-2010-1027-01-RS 